\title{
Biotechnological Reuse of Fruit Residues as a Rational Strategy for Agro-industrial Resources
}

\author{
Bruno Alexandre de Araújo Sousa, Roberta Targino Pinto Correia'
}

\begin{abstract}
Brazil, one of the largest agricultural producers in the world, has managed in recent years to significantly improve its production. However, in response to this advance in the agro-industrial sector, the generation of agro-industrial residues or sub-products has also increased, and its improper disposal may have a strong environmental impact, in addition to causing losses of raw materials and energy. In this context, the use of these residues as substrates for the production of high value-added compounds using semi-solid fermentation has been studied. Thus, the aim of this study was the physicalchemical characterization of pineapple and guava residues and their potential reuse in semi-solid cultivation. The results show that both residues are sources of bio-usable nutrients after a number of operational parameters of the bioprocess of choice are adjusted.
\end{abstract}

Keywords: pineapple guava; fruit residues; solid substrate; bioprocessing.

\footnotetext{
I Universidade Federal do Rio Grande do Norte - Depto. de Engenharia Química, Laboratório de Tecnologia de Alimentos. Av. Senador Salgado Filho, 3000, Campus Universitário, 59.072-970. Natal, RN, Brasil. Tel: +55 84 32153769, ext. 23I. E-mail: roberta@eq.ufrn.br
} 


\section{Introduction}

There is an increasing concern about environmental-linked issues around the world. As a consequence, there is a need for more effective use of resources and more efficient management of the residues produced by every economic segment. Specifically with respect to the agro-industry, these residues are mainly organic, generated in significant volumes in the food processing industry. They must be properly dealt with, since their disposal may lead to potential environmental problems, in addition to losses of raw materials and energy, requiring significant investments in pollution control (Pelizer at al., 2007). It should be pointed out that there is an important distinction between the terms solid residue and waste. The former refers to value-added materials that can be reused, whereas the latter has no value and must be discarded. Despite this important differentiation, some of the agro-industrial production units in Brazil simply dispose of the solid residues produced, because they are unaware of appropriate reuse strategies. This disposal, which often occurs improperly, may contaminate water resources or the soil.

According to Soccol and Vandenberghe (2003), the Brazilian economy is one of the most important agriculture-based economies in the world. It produces considerable amounts of coffee, sugar cane, soy, manioc and fruits, both for the internal market and for export, contributing significantly to the growth and development of the country. The Northeast of Brazil, for example, is an important producer of tropical fruits such as pineapple, avocado, banana, cashew, coconut, papaya, mango, passion fruit, grapes, acerola and guava (Lousada Júnior at al., 2006). In this region, industrial fruit processing is a major industry and along with the main products (juices, essential oils, aromas, ice-creams, jams and pulps), produces high amounts of fruit residues that can reach levels equal to $50 \%$ of the original raw material (Rodrigues, 2006).

Pineapple (Ananas comosus) and guava (Psidium guajava L.) are important tropical fruits grown in Brazil. Pineapple, a tropical crop believed to have originated in Central and South America, has spread throughout the tropical world. Brazil is the pineapple world leading producer and it is also grown extensively in Thailand and the Philippines (FAO, 2009). It is the world's most popular non-citrus tropical and subtropical fruit, according to Montero-Calderon at al.
(2008). It is generally seen as a tropical fruit-symbol which is very well appreciated all over the world by its excellent sensory qualities and its adaptation system of photosynthetic carbon fixation allows it to be highly productive in limited water availability conditions (Azevedo at al., 2007). On the other side, guava, an important member of the Myrtaceae family, is believed to have originated in Central America. It grows throughout the tropics and sub-tropics and is one of the most widely consumed tropical fruits. The world leading producer of fresh guava production is India. Brazil is among the top six world producer countries (FAO, 2009). It shows great potential for the processing industry, mainly due to high contents of vitamins $C$ and $A$.

The great Brazilian fruit production leads also to an important parallel agro-industrial residue production. These residues constitute a heterogeneous mixture of seeds, husks and skins and account for $4 \%$ to $12 \%$ and $15 \%$ to $25 \%$, respectively of the total mass of guava and pineapple produced (Mantovani at al., 2004; Rogério at al., 2007).

An alternative to reusing this commercially worthless raw material is as substrate for biotechnological purposes, in particular, fermentation in solid medium or semi-solid cultivation (SSC). This important bioprocess is characterized by microbial growth in insoluble substrate, in the presence of small amounts of free fluid, using the nutrients and residual elements present in these residues (Pinto at al., 2005). Even though this biotechnological technique has been known for centuries, it has awoken a renewed interest on the part of researchers and industries worldwide. Pandey at al. (2000), for example, affirm that the 90's have witnessed an unprecedented interest in solid state fermentation (SSF) for the development of a great number of bioprocesses, owing to a number of advantages over traditional liquid fermentation, especially in terms of the beneficial reuse of solid residues and biomass production. Recently, the genetic handling of fungal strains opened new perspectives for semi-solid cultivation, enabling the production of recombinant proteins and high value-added chemical products (Singhania at al., 2009).

Furthermore, a number of advantages of semi-solid fermentation lie in its environmentally-friendly nature, given that the processes are conducted in the absence of a free liquid phase, a situation that leads to minimum water 
consumption and low wastewater generation, in addition to not requiring the addition of anti-foaming agents, as commonly occurs in liquid fermentation. Moreover, in a large number of SSC processes the carbon and energy sources responsible for microorganism growth are the agro-industrial residues themselves, as previously mentioned (Holker and Lenz, 2005).

Semi-solid cultivation is especially promising for countries with significant agro-industrial production, such as Brazil, in which important volumes of residue are generated. This strategy enables the production of an assortment of valueadded products, including phenolic compounds (Correia at al., 2004a, 2004b; Randhir \& Shetty, 2007), organic acids (Kumar at al., 2003), proteins (Correia at al., 2007), enzymes (Botella at al., 2007; Rodriguez at al., 2006; Zheng and Shetty, 2000), and small-volume high-cost products such as biopharmaceuticals (Singhania at al., 2009).

The selection of solid substrates is essential for the success of the fermentation process, since in SSC, the availability of nutrients and the physical-chemical aspects of the substrate have a direct relationship with both growth rate and the synthesis of extracellular enzymes and secondary metabolites (Viniegra-Gonzalez, 1997). Several factors must be considered in the selection process, such as those related to cost and substrate availability (Pandey at al., 2000; Couto and Sanromán, 2006), in addition to structure, particle size distribution and composition. All these parameters are deeply related to the type of suitable microorganism for the process, since every organism has its own requirements of growth. Pandey at al. (2000) believe that the exploitation of filamentous fungi and yeast for the production of various products is important, although attempts also have been made to explore the possibilities of using bacterial strains in SSF systems. For this reason, data on the physical-chemical characterization of various types of substrate are needed for a correct choice and later use in bioprocesses.

Therefore, pineapple and guava husks were chosen for the present study, because they are generated in particularly high amounts in Brazil, owing to the fact that the country is one of the world's major producers of these two fruits (FAO, 2009). Thus, this study evaluated the physicalchemical characterization of pineapple and guava residues, assessing their potential use as substrates for the promising biotechnological technique of semi-solid cultivation. The characteristics of the residues are discussed together with their potential use or restrictions considerations as substrates for solid substrate fermentation.

\section{Method}

\section{Material}

\section{Fruit residues}

Pineapple and guava residues were obtained from fruit pulp production units in Natal, Brazil. The residues were dried in perforated nylon trays in a forced air oven at $80^{\circ} \mathrm{C}$ for four hours, then ground in a domestic multiprocessor and stored frozen until later use.

\section{Procedure}

\section{Particle size distribution, apparent density and physical-chemical characterization}

Particle size distribution was assessed using $50 \mathrm{~g}$ of residue in a PRODUTEST sieve agitator at frequency 10 for 5 minutes, in a set consisting of 6 mesh $(3.360 \mathrm{~mm}), 10$ mesh $(2.000 \mathrm{~mm}), 24$ mesh $(0.710 \mathrm{~mm}), 28$ mesh $(0.599 \mathrm{~mm}), 32$ mesh $(0.500 \mathrm{~mm}), 48$ mesh $(0.297 \mathrm{~mm})$ sieves plus the bottom. The material retained in each sieve was weighed and the results expressed in weight percentages of the original material. To determine apparent density, $100 \mathrm{~g}$ of the material was transferred without compaction to a measuring glass to calculate the volume occupied.

Guava and pineapple residues were characterized for $\mathrm{pH}$, moisture and water activity, using the analytical norms proposed by the Adolfo Lutz Institute (BRASIL, 2005). Determinations of mineral residue (ashes), acid detergent fiber (ADF), neutral detergent fiber (NDF), and raw fat and protein were analyzed according to Silva (1998). Reducing sugars (RS) and total reducing sugars (TRS) were determined using 3.5 dinitrosalicilyc acid method (DNS), according to Correia at al. (2007). The physical-chemical analyses were conducted in triplicate.

\section{Results}

The particle size distribution of dried pineapple and guava residues is shown in Figure I. The results demonstrate that dried guava waste consists mainly of small diameter particles, while dried pineapple particles have larger 
diameters, with $40 \%$ measuring more than $0.710 \mathrm{~mm}$. The pineapple residue is characterized by elongated, fibrous particles, unlike compact guava residues, which have a granular aspect. The pineapple residue has low apparent density $(0.316 \mathrm{mg} / \mathrm{mL})$ when compared to that of guava $(0.514 \mathrm{mg} / \mathrm{mL})$.

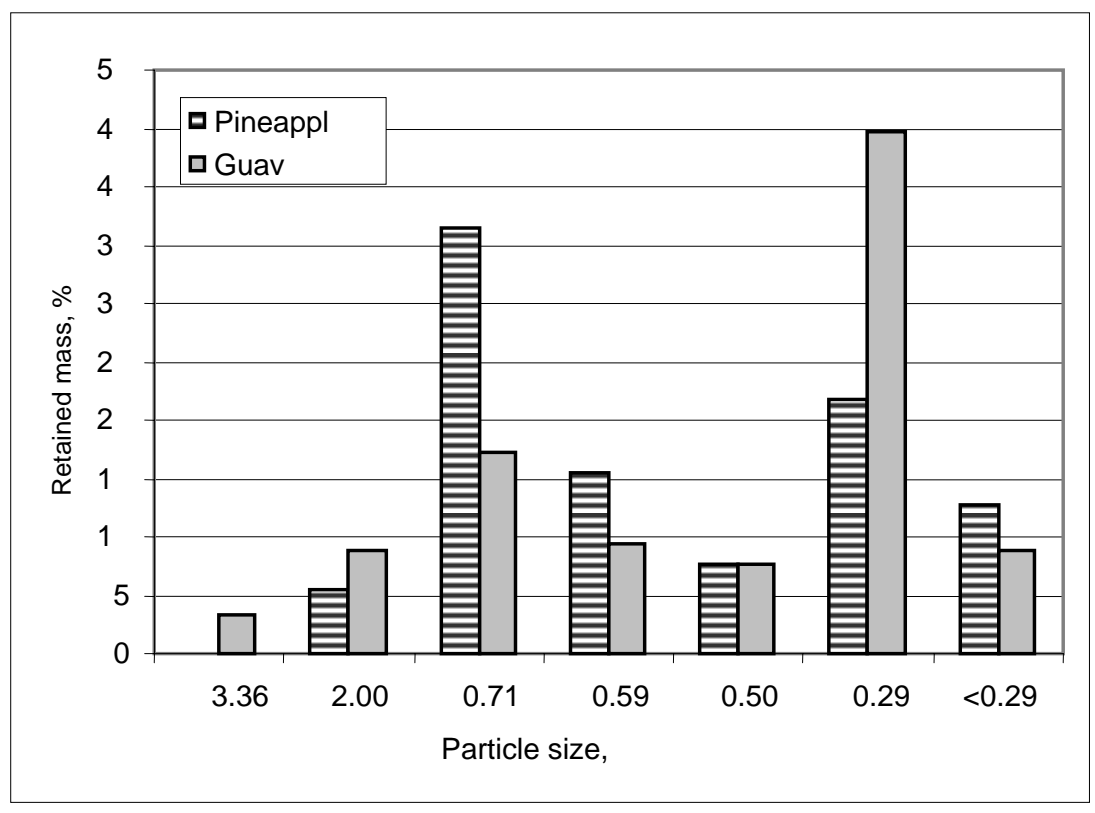

Figure I. Particle size distribution of pineapple and guava residues

The $\mathrm{pH}$ of the residues is around 4 and that pineapple is more acidic than guava (Table I). This parameter influences semi-solid fermentation itself, given that production and microbial growth depend on the initial value of the $\mathrm{pH}$ in the medium.

\begin{tabular}{lcc}
\hline & & \\
& & \\
\cline { 2 - 3 } $\mathrm{pH}$ & Pineapple residue & Guava residue \\
Moisture (\%) & $3.89 \pm 0.14$ & $4.16 \pm 0.18$ \\
Water activity & $15.97 \pm 1.14$ & $5.20 \pm 0.26$ \\
Ash (\%) & $0.62 \pm 0.03$ & $0.48 \pm 0.00$ \\
Total reducing sugars (g/lo0g) & $1.60 \pm 0.07$ & $1.95 \pm 0.13$ \\
Reducing sugars(g/l00g) & $50.30 \pm 1.16$ & $15.10 \pm 1.59$ \\
Acid detergent fiber (\%) & $30.89 \pm 1.45$ & $12.90 \pm 0.43$ \\
Neutral detergent fiber (\%) & $16.79 \pm 0.67$ & $54.22 \pm 0.61$ \\
Fat (\%) & $35.06 \pm 0.77$ & $62.19 \pm 1.49$ \\
Protein, \% & $0.15 \pm 0.15$ & $7.99 \pm 0.12$ \\
\hline
\end{tabular}

Table I. Physical-chemical characterization of pineapple and guava residues. 
Dried guava reached a lower moisture level than that of dried pineapple, a fact that also explains the different water activity values. Owing to the low initial water activity of the two residues, the addition of water or nutrient solution to the medium must be done to reach ideal levels for the development of the microorganism selected for cultivation (Sousa, 2009).

The mineral residue of guava was higher than that of pineapple, likely due to the presence of seeds. Lousada Júnior at al. (2006) found higher mineral residue values for the pineapple sub-product than those of guava, because of the presence of husks in the residue. The residue used in the study did not contain a significant amount of husks, but rather was composed mainly of pulp and stalk residue.

The pineapple residue stands out for having greater sugar content when compared to guava. This finding was previously confirmed by Correia (2004), a result that led to the investigation of the protein enrichment of pineapple residue by yeast (Correia at al., 2007).

Both residues had elevated contents of insoluble fibers, expressed as acid detergent fiber (ADF) or neutral detergent fiber (NDF). The higher levels of fibers observed in guava are also attributed to the presence of seeds found in these residues. In addition, by using the difference between NDF and ADF, one can estimate the hemicellulose content of the residue, which is a less resistant and more digestible component than cellulose. The hemicellulose content for pineapple was quite higher (I8.27\%) than that of guava (7.97\%).

Lousada Júnior at al. (2006) also observed higher NDF and ADF levels in guava than in pineapple. The authors found similar fiber values for guava, but higher values for pineapple. It should be reiterated that in the study conducted by Lousada Júnior at al. (2006), the pineapple residue was also composed of husk. The authors identified similar protein values (8.47\%) and higher fat values (6.01\%) for the guava residue compared to those found for pineapple $(8.35 \%$ and $1.19 \%$, respectively). Despite the difference in protein content in pineapple caused by the presence of husk in the residue, these results confirm those obtained in the present study, especially the much higher fat content found in guava residue, compared to that of pineapple.

\section{Discussion}

The results show important differences between the particle size distribution of the two residues, given that dried guava residue contains smaller particles compared to dried pineapple residue particles. In addition to the size differences, it can be clearly observed that the residues have different aspects and structures, since guava particles exhibit a fine granular aspect and dried pineapple is fibrous, with a spongy texture consisting of elongated particles. These structural differences have an important influence on density, and consequently on the tendency towards compaction, important parameters for cultivation in solid medium. The physical characteristics of the substrate affect the gas transfer through the process bed, thereby influencing microbial growth and metabolite synthesis, which, in turn, affect the performance of the process as a whole. The fact that pineapple residue has longer, irregularly sized particles leads to the formation of a larger number of empty spaces in the fermentation bed, a situation that explains the lower apparent density observed $(0.316 \mathrm{mg} / \mathrm{mL})$. Guava residue, however, has small particles, greater apparent density $(0.514 \mathrm{mg} / \mathrm{mL})$ and tends to compact easily, a feature that hinders its water absorption capacity, and possibly the transport of enzymes and metabolites between the medium and the microorganism (Viniegra-Gonzalez, 1997; Sousa, 2009).

The effect of particle size distribution has been studied for several systems. Banerjee at al. (1995), for example, evaluated the residues of a corn culture for protein enrichment by the Neurosphora fungus and showed that smaller particles favored protein enrichment of the residue, when associated to treatment with caustic soda.

Initial $\mathrm{pH}$ in the medium is one of the fundamental aspects for the progression of semi-solid fermentation, given that each microorganism has optimum $\mathrm{pH}$ values for its growth. The pineapple and guava residues could be indicated for processes involving the filamentous fungus Rhizopus oligosporus, since, according to Nagel at al. (1999), its optimum growth range is between 4.0 and 6.5. An adjustment of initial $\mathrm{pH}$ is needed for bacterial growth, given that this type of microorganism normally develops better in neutral $\mathrm{pH}$. It is also worth remembering that microbial growth and metabolism lead inevitably to modifications in hydrogen ion balance and consequently, 
$\mathrm{pH}$ variations are expected over the course of the bioprocess (Elibol, Moreira, 2005; Yang, 1988).

Another important $\mathrm{pH}$-related aspect is that acid values limit bacterial contamination of the fermentation medium (Menezes at al., 1998; Yang, 1988). This aspect is important because it simplifies production and makes sterilization procedures, which increase costs and productive stages in the entire process, unnecessary.

The preparation of the substrate for the fermentation process must take water activity and ideal moisture levels into account, since the amount of water present in the substrates is a limiting parameter that may directly affect microbial growth, biosynthesis and the secretion of different metabolites. In light of the reduced water activity and moisture in both substrates, moisturizing the substrate is a requisite for growth. This is performed according to the requirements of the microorganism chosen for the bioprocess. Most of the bacteria need higher water activity values to grow, compared to fungi and yeasts. In an earlier study, Alcântara at al. (2007) also found the need to add water to cashew fruit residue in the production of pectinases for semi-solid cultivation.

Moisture content may vary during fermentation, as a consequence of modifications induced by the microbial metabolism or physical parameters. Yang (1988) for example, showed that moisture in sweet potato residue increased over the course of the process, a tendency also observed by Correia at al. (2007) and which might be explained by the formation of water as a metabolic product of the fungus used in the study. Menezes at al. (1989), in turn, showed that forced aeration of the medium leads to dehydration and a consequent reduction in moisture content.

According to Pérez-Guerra (2003), the optimum moisture value depends on the nature of the solid matrix and on the needs of the microorganism used. They report that a low moisture level hinders microbial growth, given that the diffusion of solutes (nutrients) and oxygen gas is compromised. High values, in turn, reduce medium porosity, limiting oxygen transfer, in addition to posing a risk of bacterial contamination.

The mineral residue content of both residues is comparable to other types of residues reported in the literature, such as $2.0 \%$ for apple (Villas-Bôas at al., 2003), $1.07 \%$ for cashew fruit (Stamford at al., 1988) and between $3 \%$ and $4 \%$ for citric residues (Menezes at al., 1989).

Even though guava residue has lower total reducing sugar content (15.10\%), compared to pineapple (50.30\%), it can be used by microorganisms that have lower requirements in terms of sugar availability. Free sugar content is an important item in residue composition, since the literature indicates that the sugars present in the medium act as efficient sources of carbohydrates for microbial growth. Ekundayo \& Carlier (1964), for example, show that Rhizopuz arrhizus needs glucose or fructose in the medium to grow, in addition to sources of nitrogen.

The determination of acid detergent fiber (ADF) and neutral detergent fiber (NDF) enables the differentiation of different fibrous fractions using specific reagents, denominated detergents. Thus, ADF expresses lignin and lignocellulose, whereas NDF allows the identification of cellulose, hemicellulose, lignin and lignified protein content (Silva, 1998). The results show that both residues, but mainly guava, have elevated levels of insoluble fibers. The cellulose fraction, which accounts for a large part of ADF content, is especially high in guava residue. This result, associated to the lower hemicellulose content, shows that pineapple residue is potentially easier to digest than guava. The use of cellulolytic microorganisms is indicated for the latter. These microorganisms have a special ability to degrade cellulose, such as strains of the filamentous fungi filamentosos Aspergillus niger, Rhizopus sp., and Pleorotus ostreatus (Menezes at al., 1989). However, Villas-Bôas at al. (2003) showed that the yeast C. utilis has the capacity to improve the digestibility of lignocellulosic substrates, a novel behavior for yeasts, which normally require a presaccharification stage to be able to use lignocellulose as a source of carbon.

The physical-chemical characterization of both residues shows that they are sources of bio-usable nutrient residues and that they can be metabolized by different classes of microorganisms, mainly fungi and yeasts, characterized by their capacity to efficiently reuse fiber and sugar residues.

According to Holker and Lens (2005), the solid substrate fermentation (SSF) processes can bring direct economical advantages that have much to say for an intensive biotechnological application. For instance, calculation of 
the costs of production of crude enzymes by SSF showed that, for example in the case of cellulase production, the economical efficiency is much higher than in the case of the traditional submerged fermentation. This great difference has several reasons. In addition to the much cheaper growth substrates, the minimized requirements for sterility and low requirements for instrumentation and equipment, this approach can make downstream processes in the production of products such as enzymes, unnecessary.

Knowing the characteristics of agro-industrial substrates, abundantly found in a large number of countries, provides a better understanding of the beneficial reuse of this material in biotechnological processes. This is an innovative strategy with great technological potential that brings value to commercially worthless residues, while diminishing the environmental risks posed by these residues. Being so, similar studies should be conducted in order to evaluate the biotechnological potential of other agro-industrial materials, available locally in other countries. In addition to that, an economical approach about the reuse of fruit residues in Brazil or other important world fruit producers would be relevant and useful to bring more information about this important subject.

\section{References}

ALCÂNTARA, S. R., Almeida, F. A. C., Silva, F. L. H. (2007). Emprego do bagaço seco do pedúnculo do caju para posterior utilização em um processo de fermentação semi-sólida. Revista Brasileira de Produtos Agroindustriais, Campina Grande, 9, pp. I37-142.

AZEVEDO, P., Souza, C., Silva, B., Silva, V. (2007). Water requirements of pineapple crop grown in a tropical environment, Brazil. Agricultural Water Management, 88, pp. 20I-208.

BANERJEE, U., Chisti, Y., Moo-Young, M. (1995). Effects of substrate particle size and alkaline pretreatment on protein enrichment by Neurosporasitophila.Resources, Conservation and Recycling, 13, pp. I39-146.

BOTEllA,C., Diaz, A., Ory, I., Webb, C., Blandino, A. (2007). Xylanase and pectinase production by Aspergillus awamori on grape pomace in solid state fermentation. Process Biochemistry, 42, pp. 98-101.
BRASIL (2005) Ministério da Saúde. Agência de Vigilância Sanitária (ANVISA). Instituto Adolfo Lutz. Métodos FísicoQuímicos para Análise de Alimentos. Brasil: Ministério da Saúde.

CORREIA, R., Magalhães, M., Macedo, G. (2007). Protein enrichment of pineapple waste with Saccharomyces cerevisae by solid state processing. Journal of Scientific and Industrial Research, 66, pp. 259-262.

CORREIA, R. T. P. (2004) Estudo do cultivo semi-sólido de Saccharomyces cerevisiae e Rhizopus oligosporus em resíduo de abacaxi. 2004.163f. Tese (Doutorado em Engenharia Química). Centro de Tecnologia, Departamento de Engenharia Química, Programa de Pós-Graduação em Engenharia Química, Universidade Federal do Rio Grande do Norte, Natal.

CORREIA, R.T.P., Magalhães, M. M. A., Macedo, G. R., Shetty, K. (2004a). Production of phenolic antioxidants by the solid-state bioconversion of pineapple waste mixed with soy flour using Rhizopus oligosporus. Process Biochemistry, 39, pp. 2167-2174.

CORREIA, R., Mccue, P., Magalhães, M., Macedo, G., Shetty, K. (2004b) Phenolic antioxidant enrichment of soy flour-supplemented guava waste by Rhizopus oligosporusmediated solid state bioprocessing. Journal of Food Biochemistry, 28, pp. 408-4I8.

COUTO, S., Sanromàn, M. (2006). Application of solidstate fermentation to food industry - A review. Journal of Food Engineering, 76, pp. 291-302.

EKUNDAYO, J.A., Carlier, A.R. (1964). The germination of sporangiospores of Rhizopus arrhizus; spore swelling and germ tube emergence. Journal General Microbiology, 35, Pp. 261-269.

ELIBOL, M., Moreira, A. (2005). Optimizing some factors affecting alkaline protease production by a marine bacterium Teredinobacter turnirae under solid substrate fermentation. Process Biochemistry, 40, pp. 195I-1956.

FAO (Food and Agriculture Organization of United Nations). Faostat. Fao Statistics Division 2009. http://faostat.fao.org/site/408/DesktopDefault.aspx?PagelD $=408$ [Accessed in 08/04/20 I0] 
HOLKER, U., Lenz, J. (2005). Solid-state fermentation Are there any biotechnological advantages? Current Opinion in Microbiology, 8, pp. 30I-306.

KUMAR, D., Jain, V., Shanker; G., Srivastava, A. (2003). Utilisation of fruits waste for citric acid production by solid state fermentation. Process Biochemistry, 38(12), PP. 17251729.

LOUSADA Júnior, J. E., Costa, J. M. C., Neiva, J. M. N., Rodriguez, N. M. (2006). Caracterização físico-química de subprodutos obtidos do processamento de frutas tropicais visando seu aproveitamento na alimentação animal. Revista Ciência Agronômica, 37, pp. 70-76.

MANTOVANI, J. R., Corrêa, M. C. M., Cruz, M. C. P., Ferreira, M. E., Natale, W. (2004). Uso fertilizante de resíduo da indústria processadora de goiabas. Revista Brasileira de Fruticultura, 26, pp. 339-342.

MENEZES, T., Salva, T., Baldini, V., Papini, R., Sales, A. (1989). Protein enrichment of citrus wastes by solid substrate fermentation. Process Biochemistry, 24, Pp. 167$17 \mid$.

MONTERO-CALDERÓN, M., Rojas-Graü, M., MartínBelloso, O. (2008). Effect of packaging conditions on quality and shelf-life of fresh-cut pineapple (Ananas comosus) . Postharvest Biology and Technology, 50, pp.182189.

NAGEL, F. J., Ostra, J., Tramper, J. E., Rinzema, A. (1999). Improved model system for solid-substrate fermentation: effects of $\mathrm{pH}$, nutrients and buffer on fungal growth rate. Process Biochemistry, 35, pp. 69-75.

PANDEY, A., Soccol, C., Mitchell, D.(2000). New developments in solid state fermentation: I-bioprocesses and products. Process Biochemistry, 35, pp. II53-1169.

PELIZER, L. H., Pontieri, M. H., Moraes, I. O. (2007). Utilização de Resíduos Agro-Industriais em Processos Biotecnológicos como Perspectiva de Redução do Impacto Ambiental. Journal Technology Management. Innovation., 2, Pp. II8-127.

PÉREZ-GUeRRA, N., Torrado-Agrasar, A., López-Macias, C. \& Pastrana, L. (2003). Main characteristics and applications of solid substrate fermentation. Electronic
Journal Environmental, Agricultural and Food Chemistry, 2, Pp. 343-350.

PINTO, G. A. S., Brito, E. S., Andrade, A. M. R., Fraga, S. L. P., Teixeira, R. B. (2005). Fermentação em estado sólido: Uma alternativa para o aproveitamento e valorização de resíduos agroindustriais tropicais. Comunicado técnico on line 102(I), Pp. I-5.

RODRIGUES, C. (2006) Desenvolvimento de bioprocesso para produção de ácido cítrico por fermentação no estado sólido utilizando polpa cítrica. 93f. Dissertação (Mestrado em Processos Biotecnológicos) - Centro de Tecnologia, Departamento de Engenharia química, Programa de PósGraduação em Processos Biotecnológicos, Universidade Federal do Paraná, Curitiba.

RODRIGUEZ, J., Mateos, J., Nungaray, J., González, V., Bhagnagar, T., Roussos, S., Cordova, J., Baratti, J. (2006). Improving lipase production by nutrient source modification using Rhizopus homothallicus cultured in solid state fermentation. Process Biochemistry, 4I, pp. 2264-2269.

ROGÉRIO, M.C.P., Borges, V., Neiva, J.N.M., Rodriguez, N.M., Pimentel, J.C.M., Martins, G.A., Ribeiro, T. P., Costa, J.B., Santos, S.F., Carvalho, F.C. (2007). Valor nutritivo do resíduo da indústria processadora de abacaxi (Ananas comosus L.) em dietas para ovinos. I. Consumo, digestibilidade aparente e balanços energético e nitrogenado. Arquivo Brasileiro de Medicina Veterinária e Zootecnia, 59, pp. 773-78I.

RANDHIR, R., Shetty, K. (2007). Mung beans processed by solid state bioconversion improves phenolic content and functionality relevant for diabetes and ulcer management. Innovative Food Science Emerging Technologies, 8, Pp. 197204.

SILVA, D. J. (1998). Análise de alimentos: métodos químicos e biológicos. 2a. ed. Viçosa: Editora UFV. p. 165.

SINGHANIA, R., Patel, A., Soccol, C., Pandey, A. (2009).Recent advances in solid-state fermentation. Biochemical Engineering Journal, 44, pp. 13-18.

SOCCOL, C., Vandenberghe, L. (2003). Overview of applied solid-state fermentation in Brazil. Biochemical Engineering Journal, I3, pp. 205-218. 
SOUSA, B. A. A. (2009). Funcionalidade dos extratos fenólicos obtidos pelo cultivo semi-sólido de resíduos de abacaxi (Ananas comosus L.) e goiaba (Psidium guajava L.). II9f. Dissertação (Mestrado em Engenharia Química). Departamento de Engenharia Química. Universidade Federal do Rio Grande do Norte, Natal.

STAMFORD, T., Vieira, R., Guerra, N., Medeiros, R., Cavalcante, M. (1988). Protein enrichment of cashew wastes for animal feeds. Food and Nutrition Bulletin, 10, pp. 6I-64.

VILLAS-BÔAS, S., Esposito, E., Mendonça, M. (2003). Bioconversion of apple pomace into a nutritionally enriched substrate by candida utilis and Pleurotus ostreatus. World Journal of Microbiology and Biotechnology, 19, pp. 46I-467.

VINIEGRA-GONZALEZ, G. (1997). Solid state fermentation: definition, characteristics, limitation and monitoring, Pp. 5-22. In: ROUSSOUS, S. at al. (Eds.) Advances in solid-state fermentation. Dordecht: Kluwer Academic Publishers.

YANG, S. (1988). Protein enrichment of sweet potato residue with amylolytic yeasts by solid-state fermentation. Biotechnology and Bioengineering, 32, pp. 886-890.

ZHENG, Z., Shetty, K. (2000). Solid waste production of polygalacturonase by Lentinus edodes using fruit processing wastes. Process Biochemistry, 35, pp. 825-800.

\section{About the Authors}

Bruno Alexandre de Araújo Sousa is Masters in Chemical Engineering from the Universidade Federal do Rio Grande do Norte - UFRN (Brazil). Experienced in semi-solid fermentation research, with an emphasis on the production of functionally active phenolic compounds.

Roberta Targino Pinto Correia is Bachelor of Chemical Engineering and Masters in Nutrition from the Universidade Federal de Pernambuco (Brazil). Doctorate in Chemical Engineering from UFRN (Brazil) and the University of Massachusetts (USA). Experienced in Food Science and Technology, with an emphasis on semi-solid fermentation for different purposes, in addition to the processing of foods of animal origin and studies on food functionality. Adjunct professor (level III) at UFRN (Brazil) of undergraduate Food Engineering disciplines and in the Postgraduate Program in Chemical Engineering (PPGEQUFRN). 